\title{
Assessment of Stirred Probiotic Yogurt fortified with Husk Tomato (Physalis peruviana, L) Juice as a Healthy Dairy Product
}

\author{
Jihan M. Kassem $^{1, *(\mathbb{D})}$, Eman M. Hegazy ${ }^{2(\mathbb{D})}$, Afaf O. Ali ${ }^{3(\mathbb{D})}$, Hoda S. El-Sayed ${ }^{1(\mathbb{D})}$ \\ 1 Dairy Department, Food Industries and Nutrition Division, National Research Centre, $33^{\text {th }}$ Bohoth Street, Dokkii, Giza \\ 2 Food Toxicology and Contaminants Department, Food Industries and Nutrition Division, National Research Centre, $33^{\text {th }}$ \\ Bohoth Street, Dokkii, Giza \\ 3 Regional Centre of Food and Feed, Agriculture Research Center, Giza, Egypt \\ * Correspondence: jihankassem997@gmail.com;
}

Scopus Author ID 55928868300

Received: 8.05.2021; Revised: 15.07.2021; Accepted: 20.07.2021; Published: 31.10.2021

\begin{abstract}
Consumers are increasingly aware of the consumption of natural health products. Husk Tomato fruit is a remarkable fruit in a modern survey. Therefore, this study aims to produce novel stirred probiotic yogurt (SPY) fortified with Husk Tomato Juice (HTJ). Chemical, microbiological, toxins, color, and viscosity characteristics for the new product were evaluated. Vitamins A, $\mathrm{B}_{1}, \mathrm{~B}_{2}, \mathrm{C}$, amino acid profile, and the effect of HTJ or SPY on the growth of some pathogens were assessed. Vitamin A and $\beta$-carotene for fresh stirred probiotic yogurt were also analyzed. On the other side, the control sample (with no fortification) and four treatments of SPY were produced with different ratios of Husk Tomato Juice $\mathrm{T}_{1}, \mathrm{~T}_{2}, \mathrm{~T}_{3}$, and $\mathrm{T}_{4}$ with $(20,30,40$, and $50 \% \mathrm{~V} / \mathrm{V})$ respectively. Apparent viscosity, color parameters, and $\mathrm{pH}$ values of fermented beverage samples were estimated. Data revealed that the juice had a considerable vitamin $\mathrm{C}$ ratio, representing about $32-38 \%$ of the recommended daily use. On the same line, Lysine, Leucine, Valine, Threonine, Tryptophan, and Isoleucine were the main essential amino acids in the juice. Also, the HTJ possessed diverse degrees of inhibition opposite to grow of some pathogenic bacteria and fungi. The counts of starter cultures of yogurt and $L b$. case $i$ as the probiotic strain increased during the storage period until 10 days, especially in $T_{1}, T_{2}$, and $T_{3}$. The viable counts of pathogenic strains in the contaminated treatments decreased during storage periods compared with control. Furthermore, treatment samples had significantly lower $\mathrm{L}$ values and higher $\mathrm{a} \& \mathrm{~b}$ values due to the orange color of the high ratio of $\beta$-carotene in HTJ compared to control samples. A healthy probiotic fruity beverage had been successfully produced. It has appropriate amounts of important vitamins.
\end{abstract}

Keywords: husk tomato fruit; probiotic bacteria; color parameters; apparent viscosity; stirred yogurt.

(C) 2021 by the authors. This article is an open-access article distributed under the terms and conditions of the Creative Commons Attribution (CC BY) license (https://creativecommons.org/licenses/by/4.0/).

\section{Introduction}

Evolutions of functional dairy beverages are now an essential stimulus in dairy markets in many regions such as Asia, Africa, Europe, the Middle East, and South America. The fermented dairy products field is increasing in the food industry as current health-conscious consumers manifest expanding demand for food that can improve well-being and minimize the risk of diseases. Fermented milk, especially yogurt-style products, is the most marketable functional beverage [1,2]. Yogurt, which is considered a "functional food" is one of the most popular food products due to the promising behavior of probiotic bacteria [3]. 
International Dairy Federation explained that the milk product prepared from skimmed milk or not with specific cultures is called fermented milk products. The microflora must be > $10^{6}$ organisms/g live lactic acid bacteria till sale to the customers [4, 5, 6]. Jalal et al. [7] elucidated that to reduce the risk of several diseases, it is recommended to consume an adequate amount of milk and fermented dairy products as a part of a healthy diet. Probiotics are living microorganisms, which beneficially affect the host's health by enhancing the composition of intestinal microflora when ingested in sufficient amounts. The most common genera and species are Lactic Acid Bacteria (LAB) from the genera Lactobacillus such as (Lactobacillus acidophilus, Lactobacillus casei) and Bifidobacterium, as are considered Generally Recognized as Safe (GRAS) [8, 9].

Furthermore, the fortification of fermented milk is a good strategy to promote nutrient intake in daily food products [10]. Fermented dairy products contain adequate levels of certain live and active cultures, namely probiotics that aid in developing the balance of "beneficial" facing "undesirable" bacteria in the intestinal tract [11]. Recently, functional drinks have been used to improve health and immune status, help lose weight, and counteract aging symptoms.

Husk Tomato (Physalis pubescens L.) fruit has been known in Egypt under the name of its varieties 'Harankish', 'Halawyat' and 'El-Set El-Mestihya'. Recently, Husk Tomato is a very hopeful fruit; its economic importance has been raised due to its high admittance for local consumption, achieving great success in the African, Latin American, and European markets [12-14]. It was also a good source of pro-vitamin A, vitamin C, vitamin B-complex, and several minerals of nutritional importance. Polyphenols in the fruit demonstrate antiinflammatory and antioxidant properties [15,16].

Otherwise, contaminated Husk Tomato and other fruit with fungi that produced mycotoxins are considered a great problem in trade markets. Mycotoxins had a spectacular influence on human health and animals who suffered from many illnesses [17,18]. There is various genus of Aspergillus, such as A. flavus, and A. parasiticus are known to produce harmful, mutagenic, and carcinogenic toxins during metabolism like coumarins derivatives $[19,20]$. About 18 types of aflatoxins (AF) are documented, especially hydroxylated M type, which can be insulated from dairy products. The serious problem in the fruit and juice industry, especially apple and pear, is the contamination with patulin after molds' growth. While this problem appears during the production of fresh juice (cloudy) or minimally fruit products, it rarely or disappears during manufacture [21].

Hence, this research is a continuation of a previous study [14]. Analyze Husk Tomato Juice for its contents of vitamins $\left(A, B_{1}, B_{2}\right.$, and $\left.C\right)$ and amino acid profile. The ability of fungi to produce mycotoxins under storage in a refrigerator for two weeks was assessed. Therefore, a novel probiotic beverage fortified with Husk Tomato "Harankish" fruit had been produced. Some chemical and antimicrobial properties of this product had also been evaluated during storage.

\section{Materials and Methods}

\subsection{Materials.}

Milk: Fresh full-fat buffalo's milk was purchased from the Faculty of Agriculture's farm, Cairo University, Giza.

Lactic acid strains: Lactobacillus delbrueckii subsp. bulgaricus Lb-12 DRI-VAC had been provided by Northern Regional Research Laboratory. Illinois, USA. Streptococcus 
thermophilus $\mathrm{CH}-1$ and Lactobacillus casei FEGY 9973 were obtained from our culture collection, Department of Dairy Science, Faculty of Agriculture, Cairo University, Egypt.

Pathogenic strains: Bacillus cereus B-3711 and Aspergillus flavus 3357 were provided by the Northern Regional Research Laboratory Illinois, USA (NRRL). Escherichia coli 0157: H7 and Staphylococcus aureus were isolated and serologically identified by the dairy microbiological Lab., National Research Centre.

Husk Tomato fruits and Sugar: Fine grade of Husk Tomato fruits and sugar were bought from a hypermarket in Giza, Egypt.

\subsection{Methods.}

2.2.1.Preparation of husk tomato juice (HTJ).

Husk Tomato Juice was prepared, as mentioned in the previous study [14].

\subsubsection{Preparation of stirred probiotic yogurt (SPY).}

Sugar with $7 \%$ ratio was added to fresh buffalo milk and was pasteurized at $75^{\circ} \mathrm{C} / 10$ sec. Then cooled to $42^{\circ} \mathrm{C}$ [22]. After that, both starter cultures (1:1\%) of St. thermophilus and Lb. bulgaricus and probiotic bacteria ( $\mathrm{Lb}$. casei) at a ratio of $(1 \%)$ were added at $37^{\circ} \mathrm{C}$, respectively. Then the curd was divided to gain five treatments; first, as control (without fruit), second, third, fourth, and fifth treatments had been blended with HTJ at ratios of 20, 30, 40, and $50 \%(\mathrm{v} / \mathrm{v})$ served as $\mathrm{T}_{1}, \mathrm{~T}_{2}, \mathrm{~T}_{3}$ and $\mathrm{T}_{4}$ \{Preparation of SPY mentioned in details in the published paper [14]. The fermented treatments were analyzed when fresh and after 5, 10, and 15 days of cold storage.

Another separated contaminated samples with a mixture of four pathogenic strains obtained by mixing the same population $\left(\sim 10^{6} \mathrm{CFU} / \mathrm{ml}\right)$ of different strains of each microorganism. The inoculated milk was divided into five treatments as previously.

\subsubsection{Determination of vitamins.}

Vitamin A and Vitamin $\mathrm{B}_{1} \& \mathrm{~B}_{2}$ were determined according to Danish Official HPLC method No. AF $255.13^{\text {th }}$ and No. AB 198.2, respectively [23,24]. Additionally, Vitamin C was determined according to Indian Standard Methods for Estimation of Vitamin C in Foodstuffs [25].

2.2.4. Determination of amino acid contents.

HPLC estimated amino acid contents of Husk Tomato Juice according to the method [26].

\subsection{5. $\mathrm{pH}$ measurement.}

The $\mathrm{pH}$ values of all samples were measured using a digital laboratory $\mathrm{pH}$ meter (HI 93 1400, Hanna instruments) with a glass electrode.

\subsubsection{Apparent viscosity.}

The treated samples were gently stirred 5 times clockwise with a plastic spoon before viscosity measurements. Apparent viscosity was measured at $5 \pm 2^{\circ} \mathrm{C}$ using a Brookfield digital viscometer (Model DV-II, Canada) fitted with spindle-4. The FHTB samples were subjected 
to selected shear rates ranging from 3.0 to 50.0 S1 for the upward curve. Apparent viscosity was expressed as Pascal (Pas).

\subsubsection{Color parameters.}

The color was estimated for treatment samples by using Hunter Colorimeter model D2s A-2 [27]. Tri-stimulus values of the color, namely $L$, $a$, and $b$, were measured.

Where: L: Values represent darkness from black (0) to white (100); a: Values represent color ranging from red (+) to green (-); b: Values represent colors ranging from yellow (+) to blue () .

\subsubsection{Microbiological analysis.}

Lactobacillus bulgaricus counts were determined using MRS agar, according to De Man et al., [28]. Streptococcus thermophilus counts were determined using M17 agar according to Teraghi and Sandine [29]. The counts of Lactobacillus casei were determined using MRS agar free from sugar and supplemented with $0.05 \%$ cellobiose, according to Shah [30]. According to Mossel, the clearest bacterial counts were counted using violet red bile agar medium [31].

2.2.9. Microorganisms count $\left(\log _{10} \mathrm{CFU} / \mathrm{ml}\right)$ in contaminated HTJ samples during storage.

One hundred $\mathrm{ml}$ of separated fresh HTJ contaminated with a mixture of four pathogenic strains (Bacillus cereus, Escherichia coli O157:H7, Staphylococcus aureus, and Aspergillus flavus) was obtained by mixing the same population $\left(\sim 10^{6} \mathrm{CFU} / \mathrm{ml}\right)$ of the different strains of each microorganism. The mixture of pathogenic strains were enumerated on the selective medium during storage at $5{ }^{\circ} \mathrm{C}$ for 15 days, Bacillus cereus agar medium, supplemented with polymyxin B and egg yolk [32] for the first, Sorbitol MacConky Agar Medium for second pathogen [33], Baird Parker Agar with egg yolk for third one [34] and potato dextrose agar pH 3.5 for the last [35]. Same pathogenic bacteria were detected in contaminated yogurt samples by the same methods mentioned previously.

\subsubsection{Isolation and identification of fungi.}

According to Nure et al. [36], the serial dilution plate method was used for isolated fungi in treatment samples during storage. The fungi count was determined and expressed as $\mathrm{CUF} / \mathrm{g}$ or $/ \mathrm{ml}$ on potato dextrose agar [37]. The identification of isolated fungi was carried out based on macro-and microscopically observations using descriptions provided according to Barnett and Hunter [38].

\subsubsection{Detection the ability of isolated fungi to produce mycotoxins.}

Detection of the ability of isolated fungi from raw materials (Husk Tomato Juice and buffalo milk) and through storage to produce mycotoxins in vitro was observed. The ability of A. flavus to produce aflatoxin $\mathrm{B}_{1}, P$. expansumt to produce patulin, and $A$. versicoular to produce sterigmatocystin by thin-layer chromatography plates (TLC) according to Muiz AlHussaini and Kadhim, [39]. Also, Aflatoxin M, patulin, and sterigmatocystin were determined in raw materials and fermented beverage throw storage according to techniques of AOAC [40] and Giovati et al., [41] then analyzed by high-performance liquid chromatography (HPLC). 


\subsubsection{Statistical analysis.}

Statistical analysis for obtained data was carried out using variance analysis (ANOVA) and Duncan tests with the Statistical Analysis System [42]. A probability of $P<0.05$ was used to establish statistical significance.

\section{Results and Discussion}

\subsection{Vitamins contents of HTJ and SPY.}

Vitamins $\mathrm{A}, \mathrm{B}_{1}$, and $\mathrm{B}_{2}$ in HTJ had been highlighted in Fig. 1; they were 0.822, 0.4, and $0.7 \mathrm{mg} / 100 \mathrm{~g}$, respectively. The Recommended Daily Allowance (RDA) of vitamin C in the United States (Institute of Medicine of the National Academy of Sciences. Food and Nutrition Board) for adults between 31 and 50 years old is $90 \mathrm{mg} /$ day for men $75 \mathrm{mg} /$ day for women. Vitamin $\mathrm{C}$, which is considered an indicator of fruit's nutritional quality, had a ratio of 28.7 $\mathrm{mg} / 100 \mathrm{~g}$, which represented about $32 \%$ and $38 \%$ of the needs for men and women/ day, respectively. At the same time, Hassanien and Morsel [43] and Labarca et al. [44] mentioned that the ascorbic acid content of fresh Rasbhari is $26.31 \mathrm{mg} / 100 \mathrm{~g}$. However, this vitamin is a great reducing agent with high antioxidant activity. Ascorbic acid also plays a serious role in human nourishment, overall growing and preserving tissues, and producing neurotransmitters, hormones, and immune system responses [44,45].

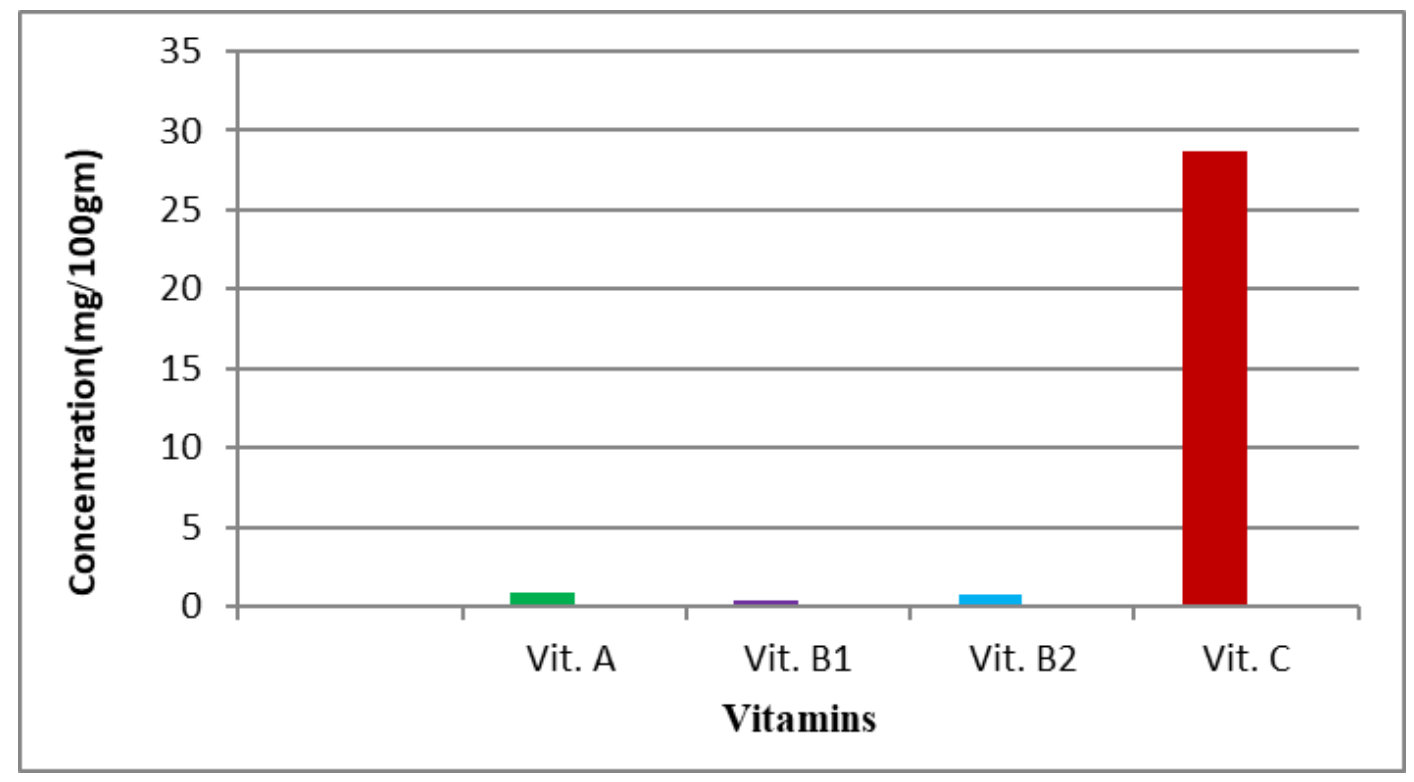

Figure 1. Vitamins contents of Husk Tomato Juice.

Vitamins $\mathrm{C}, \mathrm{E}$, and $\beta$-carotene have a Synergistic impact in scavenging reactive nitrogen species. Vitamin A is considered an important factor of standard vision, preserving the integrity of epithelial tissues and for a broad set of some metabolic activities. The reduction of vitamin A as micronutrient malnutrition is globally affecting over 3 billion people. Vitamin A Deficiency (VAD) has influenced about 190 million preschool-aged children and 19 million pregnant women, mostly in Africa and South-East Asia, as stated by World Health Organization (WHO) [46].

$\beta$-carotene and Vitamin A of fresh stirred probiotic yogurt were presented in Table 1. The results figured that $\beta$-carotene content in fresh treatment samples was significantly $(\mathrm{p}<0.05)$ higher than fresh control ones. The $\beta$-carotene contents were $(0.430,0.447,0.578$, 
and $0.685 \mathrm{mg} / 100 \mathrm{~g}$ ) for $\mathrm{T}_{1}, \mathrm{~T}_{2}, \mathrm{~T}_{3}$, and $\mathrm{T}_{4}$, respectively, against traces in the control sample. This result was logical because $\beta$-carotene is absent in buffalo milk. So, the high ratio of $\beta$ carotene content in SPY was due to the import of HTJ. These results followed Khedkar et al., [47], who mentioned that carotenoids are absent in buffalo milk. Pritwani and Mathur [48] declared the contents of $\beta$-carotene in some fruits such as ripe tomato (Lycopersicon esculentum), papaya (Carica papaya), and Cape gooseberry (Physalis peruviana), which were 316.6-341.2, 185.02- 34.28 and 775.21-857.71 $\mu \mathrm{g} / 100 \mathrm{~g}$ respectively.

Also, it was observed that the content of vitamin A was more pronounced in all treatment samples compared to control. As it is known that buffalo milk is a good source of vitamin A which is lipo-soluble (A, D, K, and E), the ratio of this vitamin depends mainly on the higher fat amount in buffalo milk. Vitamin A contents were (10.26, 14.53, 15.12, 15.89, and $16.78 \mathrm{mg} / 100 \mathrm{~g}$ ) for control, $\mathrm{T}_{1}, \mathrm{~T}_{2}, \mathrm{~T}_{3}$, and $\mathrm{T}_{4}$. The increment in vitamin A of all treatments was due to the juice contents of this vitamin besides buffalo milk content.

Table 1. $\beta$-carotene and Vitamin A of fresh Stirred Probiotic Yogurt (SPY).

\begin{tabular}{|c|c|c|c|c|c|}
\hline \multirow{2}{*}{ Vitamins Contents (mg/100g) } & \multicolumn{5}{|c|}{ Treatment samples } \\
\hline & Control & $\mathbf{T}_{1}$ & $\mathbf{T}_{2}$ & $\mathbf{T}_{3}$ & $\mathbf{T}_{4}$ \\
\hline$\beta$-carotene & Traces & $0.430^{\mathrm{A}}$ & $0.447^{\mathrm{B}}$ & $0.578^{\mathrm{C}}$ & $0.685^{\mathrm{D}}$ \\
\hline Vitamin A & $10.26^{\mathrm{a}}$ & $14.53^{\mathrm{b}}$ & $15.12^{\mathrm{bc}}$ & $15.89^{\mathrm{c}}$ & $16.78^{\mathrm{cd}}$ \\
\hline \multicolumn{6}{|c|}{$\mathrm{T}_{1}=20 \% \mathrm{HTJT}_{2}=30 \% \mathrm{HTJ} \mathrm{T}_{3}=40 \% \mathrm{HTJ} \quad \mathrm{T}_{4}=50 \% \mathrm{HTJ}$} \\
\hline
\end{tabular}

\subsection{Amino acid contents of husk tomato juice.}

Amino acid contents of Husk Tomato Juice (HTJ) were pointed in Table 2. As announced in the first published research [11], it was found that the total protein of the juice was $0.98 \%$. Obviously, lysine, leucine, valine, threonine, tryptophan, and isoleucine were the major essential amino acids found in husk tomato juice. While glutamic acid, proline, aspartic acid, alanine, and serine were the non-essential amino acids that had been estimated in fresh HTJ. There were considerable amounts of amino acids compared to those recommended by Anon FAO/WHO/UNU [49]. It was apparent that the ratios of particular amino acids isoleucine, leucine, and lysine cover the requirements for children from 2-12 years old. The same trend was found about threonine, tryptophan, and valine amino acids. As well, it could be concluded from the obvious Table that sulfur-containing amino acids supply the needs for the same age group and about half of the needs for the adult group. As mentioned by Colovic et al. [50], the action of sulfur amino acids and their derivatives (such as glutathione (GSH), thioredoxins, glutaredoxins) includes their protective role against oxygen reactive species as master antioxidants and in protein metabolism. Moreover, methionine side chains can be sited on the protein surface, influencing an endogenous antioxidant defense in proteins. Cysteine and methionine belong to a group of twenty canonic amino acids integrated into protein structures. As a component of tissue proteins, cysteine presents an essential precursor for protein synthesis. Our findings were in ceremony with EL Sheikha et al., [13], who stated that alanine, aspartic acid, glutamic acid, glycine, and proline were the superior amino acids in Physalis juice.

Table 2. Amino acid contents of fresh Husk Tomato Juice (HTJ).

\begin{tabular}{|c|c|c|c|c|}
\hline \multirow{2}{*}{ Amino acid } & \multirow{2}{*}{$\begin{array}{l}\text { Content } \\
\text { (g/100 g protein) }\end{array}$} & \multicolumn{3}{|c|}{ FAO Pattern*(g/100g protein $)$} \\
\hline & & Child 2-5 years & Child 10-12 years & Adult \\
\hline Isoleucine & 2.51 & 2.8 & 2.8 & 1.3 \\
\hline Leucine & 4.12 & 6.6 & 4.4 & 1.9 \\
\hline
\end{tabular}




\begin{tabular}{|c|c|c|c|c|}
\hline \multirow{2}{*}{ Amino acid } & \multirow{2}{*}{$\begin{array}{l}\text { Content } \\
\text { (g/100 g protein) }\end{array}$} & \multicolumn{3}{|c|}{ FAO Pattern*(g/100g protein) } \\
\hline & & Child 2-5 years & Child $10-12$ years & Adult \\
\hline Lysine & 4.34 & 5.8 & 4.4 & 1.6 \\
\hline Cysteine & 1.31 & - & - & - \\
\hline Methionine & 1.63 & - & - & - \\
\hline Total sulfur containing amino acids & 2.94 & 2.5 & 2.2 & 1.7 \\
\hline Tyrosine & 1.01 & - & - & - \\
\hline Phenylalanine & 2.28 & - & - & - \\
\hline Total aromatic amino acids & 3.29 & 6.3 & 2.2 & 1.9 \\
\hline Threonine & 3.12 & 3.4 & 2.8 & 0.9 \\
\hline Terptophane & 2.53 & 1.1 & 0.9 & 0.5 \\
\hline Valine & 3.22 & 3.5 & 2.5 & 1.3 \\
\hline Total essential Amino Acids & 26.07 & 32 & 22.2 & 11.1 \\
\hline Histidine & 2.78 & - & - & - \\
\hline Argenine & 2.33 & - & - & - \\
\hline Aspartic acid & 10.55 & - & - & - \\
\hline Glutamic acid & 17.23 & - & - & - \\
\hline Serine & 4.26 & - & - & - \\
\hline Proline & 17.09 & - & - & - \\
\hline Glycine & 3.28 & - & - & - \\
\hline Alanine & 9.11 & - & - & - \\
\hline $\begin{array}{l}\text { Total non-essential Amino Acids } \\
\text { FAO/WHO/UNU Pattern [46]. }\end{array}$ & 66.63 & & & \\
\hline
\end{tabular}

\section{3. pH measurement of stirred probiotic yogurt (SPY) during storage.}

Data in Fig. 2 displayed that all treatments supplemented with HTJ had lower pH values than control samples, either fresh or after 5, 10, and 15 days of storage. A decrease in $\mathrm{pH}$ values was ultimately proportional to HTJ concentrations. The decrease in $\mathrm{pH}$ values was a collection effect of the existence of probiotic \& starter culture and HTJ and also due to the production of organic acids. In fact, a diminish in $\mathrm{pH}$ values during cold storage was significant $(\mathrm{p}<0.05)$ after 10 and 15 days at high ratios treatments $\left(\mathrm{T}_{3} \& \mathrm{~T}_{4}\right)$. The taste of acidity was more present on the $15^{\text {th }}$ day of storage. The same outcome was found by Rozada-Sánchez et al., [51], who evaluated the $\mathrm{pH}$ range as a result of Bifidobacterium spp. addition after 14 hours of fermentation, and the range was between 4.40 and 4.6. Also, Gustaw et al. [52] pointed to the range of $\mathrm{pH}$ values of all FHTB types supplemented with $1 \%$ probiotic were 4.62 to 4.20 , lower than control samples during the storage. Also, the same results agreed with El-Sayed and Ramadan [53], who found that the $\mathrm{pH}$ values were decreased during the storage period of probiotic rice milk beverages.

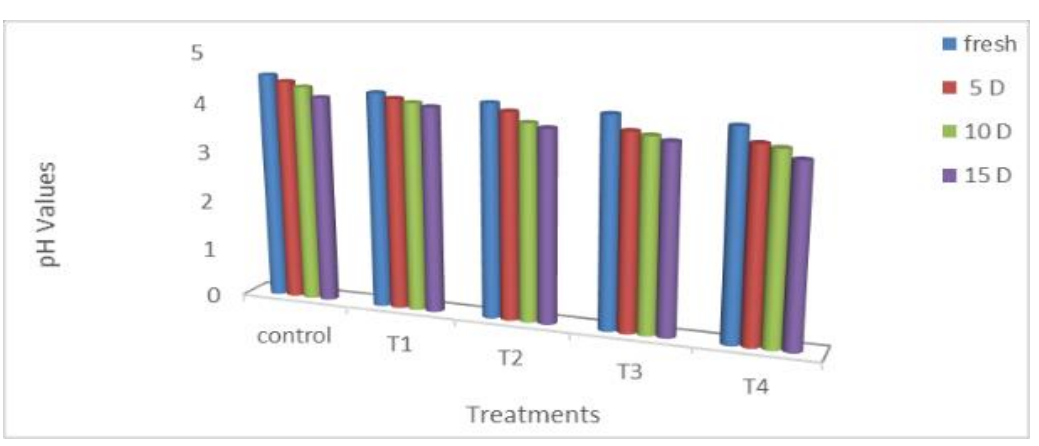

Figure 2. $\mathrm{pH}$ values of stirred probiotic yogurt (SPY) during storage.

$\mathrm{T}_{1}, \mathrm{~T}_{2}, \mathrm{~T}_{3}$, and $\mathrm{T}_{4}$ at the ratios mentioned before

\subsection{Apparent viscosity of stirred probiotic yogurt (SPY) during storage.}

In non-Newtonian fluid, the apparent viscosity depends on the share rate changes, as the shear rate is changed. As shown in Fig. 3, the apparent viscosity of control samples was 
higher than treatment samples, either fresh or during storage. As cleared in Fig. (3 a, b, c, and d), fresh control samples had significantly $(p \leq 0.05)$ higher apparent viscosity than treatments. This is because yogurt beverage represented as a matrix of casein micelles with entrapped water like in control samples. When adding the HTJ, it may split the structure of fortified samples and minimize the viscosity. As the juice concentration increased, the apparent viscosity decreased compared to the control. Increment of viscosity might be due to the production of exopolysaccharides (EPS) produced by Lactic acid bacteria like starter bacteria and Lb. casei, which interact with milk protein and increase viscosity. As it's known as heteroexopolysaccharides, Lactic acid bacteria participated in gel formation of the stirred yogurt through the formation of the EPS that inhibits syneresis of the final product. This explanation is in line with Rawson and Marshall [54], Béal and Helinck [55], Han et al. [56], and Mekhici et al. [57]. By the time, the apparent viscosity of all samples had been slightly increased until day 15. Also, these data were in correspondence with Sahan et al. [58], who announced that apparent viscosity by time could increase due to the rearrangement of protein and proteinprotein contacts. On the same line, Gilbert et al. [59] discussed the microstructure of stirred yogurt and its viscosity and firmness, which depends on interactions between molecules or particles. They found that the viscosity of yogurt is temperature-dependent; it lowers with increasing temperature. So, the yogurt gel suffers structural breakdowns during shearing; the interactions bonds and structures that define the gel are progressively broken, leading to the formation of microgels. This could be expressed by the reduction of viscosity during shearing.

\subsection{Color parameters of stirred probiotic yogurt (SPY) during storage.}

Table 3 clarifies the color parameters of SPY. It was noted that the whiteness parameter (L) was higher in control samples compared to treated ones; due to the fortification of HTJ. Therefore, more ratios of HTJ increased, the treatment was more saturated with color concentration, and the parameter (L) went away from whiteness, and this because of the featured color of the juice, which tends to be orange. $L$ values were $(91.03,85.90,82.25,79.48$, and 77.80) for control, $\mathrm{T}_{1}, \mathrm{~T}_{2}, \mathrm{~T}_{3}$, and $\mathrm{T}_{4}$ at fresh period, respectively. Then they reached (91.72, $87.06,83.13,80.89$, and 78.31) for control, $\mathrm{T}_{1}, \mathrm{~T}_{2}, \mathrm{~T}_{3}$, and $\mathrm{T}_{4}$ at the end, respectively. While the opposite trend was found in redness parameters (a), it boosted in treatment samples more than control due to the tendency of color juice to red. The treated sample $\left(\mathrm{T}_{4}\right)$ had gained the highest score compared to other samples. On the other hand, it was observed that $b$-values for treatments were more noticeable than control ones with remarkable differences in treated samples by changing the concentration juice. Carotenoids are responsible for the orange color of this beverage, especially $\beta$-carotene, which was high in HTJ. Furthermore, the b-values of treated samples were prominent higher than control ones with fewer differences between treatments by adding more juice ratios. Husk Tomato fruit is an orange color fruit with a high ratio of $\beta$-carotene; consequently, it is responsible for stirred probiotic yogurt color by decreasing $L$ value and increasing $b$ \& a value.

These results were harmonized with Yu et al., [60], who fortified yogurt with red pepper and revealed that $\mathrm{L}$ value decreased, whereas the $\mathrm{a}$ and $\mathrm{b}$ values increased significantly with the amount of red pepper added. As well as Nguyen and Hwang [61] showed that the Aronia juice which had been added to yogurt treatments made them redder, darker, and less yellow than control yogurt. 

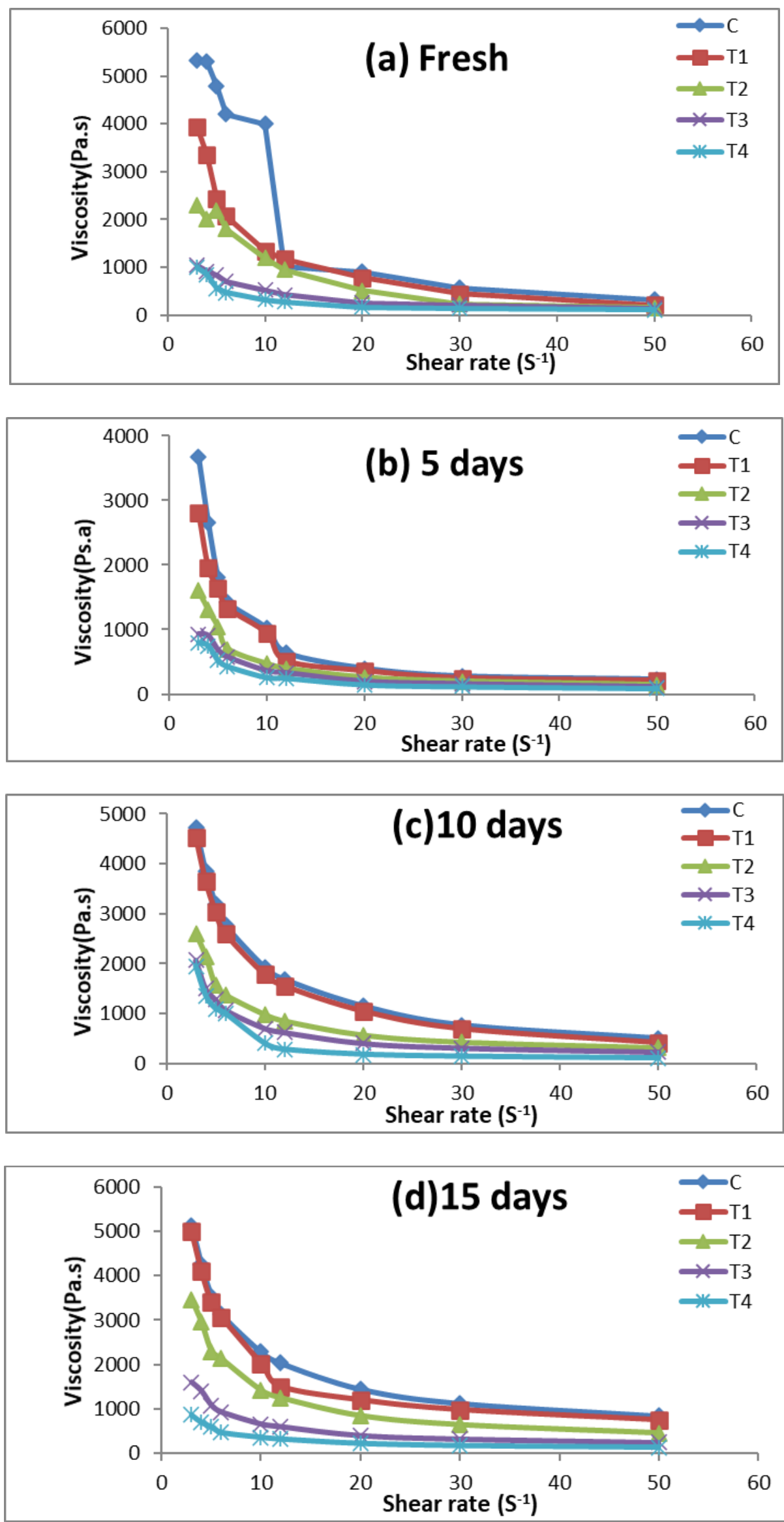

Figure 3. Apparent viscosity of Stirred Probiotic Yogurt (SPY) during storage. $\mathrm{T}_{1}, \mathrm{~T}_{2}, \mathrm{~T}_{3}$ and $\mathrm{T}_{4}$ at the ratios which mentioned before. 
Table 3. Color parameters of Stirred Probiotic Yogurt (SPY) during storage.

\begin{tabular}{|c|c|c|c|c|c|}
\hline \multirow{3}{*}{$\begin{array}{l}\text { Color } \\
\text { parameters }\end{array}$} & \multicolumn{5}{|c|}{ Treatment samples } \\
\hline & Control & $\mathbf{T}_{1}$ & $\mathbf{T}_{2}$ & $\mathbf{T}_{3}$ & $\mathbf{T}_{4}$ \\
\hline & \multicolumn{5}{|c|}{ Fresh } \\
\hline $\mathbf{L}$ & 91.03 & 85.90 & 82.25 & 79.48 & 77.80 \\
\hline $\mathbf{a}$ & -1.93 & 1.63 & 3.29 & 4.11 & 5.40 \\
\hline b & 10.77 & 22.39 & 31.82 & 36.51 & 41.93 \\
\hline \multicolumn{6}{|c|}{5 Days } \\
\hline $\mathbf{L}$ & 90.95 & 85.65 & 82.04 & 79.41 & 77.63 \\
\hline $\mathbf{a}$ & -2.03 & 1.59 & 2.97 & 4.02 & 5.39 \\
\hline b & 10.53 & 22.60 & 31.70 & 36.45 & 41.42 \\
\hline \multicolumn{6}{|c|}{10 Days } \\
\hline $\mathbf{L}$ & 90.81 & 85.36 & 81.69 & 79.32 & 77.35 \\
\hline $\mathbf{a}$ & -2.12 & 1.54 & 2.71 & 3.89 & 5.41 \\
\hline b & 10.47 & 22.88 & 31.62 & 36.40 & 41.10 \\
\hline \multicolumn{6}{|c|}{15 Days } \\
\hline $\mathbf{L}$ & 91.72 & 87.06 & 83.13 & 80.89 & 78.31 \\
\hline $\mathbf{a}$ & -1.97 & 2.02 & 3.11 & 4.51 & 6.51 \\
\hline b & 10.92 & 24.39 & 32.56 & 36.98 & 43.63 \\
\hline
\end{tabular}

3.6. Viability of starter cultures counts ( $\left.\log _{10} \mathrm{CFU} / \mathrm{ml}\right)$ of stirred probiotic yogurt (SPY) during storage.

The effect of HTJ at divers' concentrations on the growth of studied Lb. bulgaricus counts in SPY through storage were highlighted in Table 4. A little raise was observed in viable counts of Lb. bulgaricus until 10 days of storage, then decreased at 15 days of storage. The first and third treatments $\left(\mathrm{T}_{1}\right.$ and $\left.\mathrm{T}_{3}\right)$ contained the highest viable count of Lb. bulgaricus during storage versus control and other treatments. Moreover, St. thermophilus was increasing up to 10 days then decreased at the end of the storage period in all treatments. Samples with 30\% HTJ had the highest counts, the viable counts of St. thermophilus and Lb. bulgaricus reached 8.90 and $9.00 \log _{10} \mathrm{CFU} / \mathrm{ml}$ at the end for the same treatments, respectively, against control and other treatments. Also, measuring the $\mathrm{pH}$ values through the trial to control the influence of HTJ on the activity of the starter culture in the final product. These data confirmed with much literature which displayed that fruit juice that contained high amounts of minerals (iron, potassium, and phosphorus), vitamins (A, B, and C), and carotenoid can enhance the starter culture growth $[12,62,63]$.

Table 4. Viable counts of a starter of Stirred Probiotic Yogurt (SPY) during storage ( $\left.\log _{10} \mathrm{CFU} / \mathrm{ml}\right)$.

\begin{tabular}{l|c|c|c|c|c|c|c|c}
\multirow{2}{*}{ Treatments } & \multicolumn{4}{|c|}{ Lb. bulgaricus } & \multicolumn{4}{c}{ St. thermophilus } \\
\cline { 2 - 8 } & \multicolumn{3}{|c|}{ Storage periods (days) } & \multicolumn{4}{c}{ Storage periods (days) } \\
\cline { 2 - 8 } & Fresh & $\mathbf{5}$ & $\mathbf{1 0}$ & $\mathbf{1 5}$ & Fresh & $\mathbf{5}$ & $\mathbf{1 0}$ & $\mathbf{1 5}$ \\
\hline Control & $8.25^{\mathrm{Cb}}$ & $8.40^{\mathrm{Bc}}$ & $8.60^{\mathrm{Ae}}$ & $8.00^{\mathrm{Dd}}$ & $8.15^{\mathrm{Dc}}$ & $8.30^{\mathrm{Cc}}$ & $8.70^{\mathrm{Ae}}$ & $8.40^{\mathrm{Bd}}$ \\
\hline $\mathbf{T}_{\mathbf{1}}$ & $8.30^{\mathrm{Da}}$ & $8.70^{\mathrm{Bb}}$ & $8.95^{\mathrm{Ab}}$ & $8.60^{\mathrm{Cb}}$ & $7.90^{\mathrm{Db}}$ & $8.50^{\mathrm{Cb}}$ & $9.00^{\mathrm{Ab}}$ & $8.90^{\mathrm{Bb}}$ \\
\hline $\mathbf{T}_{\mathbf{2}}$ & $8.12^{\mathrm{Cc}}$ & $8.75^{\mathrm{ABb}}$ & $8.88^{\mathrm{Ac}}$ & $8.40^{\mathrm{Bc}}$ & $7.95^{\mathrm{Db}}$ & $8.65^{\mathrm{Ca}}$ & $9.20^{\mathrm{Aa}}$ & $9.00^{\mathrm{Ba}}$ \\
\hline $\mathbf{T}_{\mathbf{3}}$ & $8.00^{\mathrm{Dd}}$ & $8.90^{\mathrm{Ca}}$ & $9.12^{\mathrm{Aa}}$ & $9.00^{\mathrm{Ba}}$ & $8.00^{\mathrm{Da}}$ & $8.55^{\mathrm{Cb}}$ & $8.90^{\mathrm{Ac}}$ & $8.80^{\mathrm{Bc}}$ \\
\hline $\mathbf{T}_{\mathbf{4}}$ & $8.20^{\mathrm{Db}}$ & $8.50^{\mathrm{Cc}}$ & $8.75^{\mathrm{Ad}}$ & $8.45^{\mathrm{Bc}}$ & $8.10^{\mathrm{Ca}}$ & $8.33^{\mathrm{Bc}}$ & $8.70^{\mathrm{Ad}}$ & $8.35^{\mathrm{Bd}}$
\end{tabular}

$\mathrm{T}_{1}, \mathrm{~T}_{2}, \mathrm{~T}_{3}$ and $\mathrm{T}_{4}$ at the ratios which mentioned before. Data expressed as mean of 3 replicates. Means in the same row showing the same capital letters are not significantly different $(\mathrm{p} \leq 0.05)$. Means in the same column showing the same small letters are not significantly different $(\mathrm{p} \leq 0.05)$.

3.7. Viability of Lb. casei counts ( $\left.\log _{10} C F U / m l\right)$ of Stirred Probiotic Yogurt (SPY) during storage:

Viability of Lb. casei in SPY was seen in Table 5. The data expounded that treatments that involved 30, 40 and 50\% HTJ owned the more count of $\mathrm{Lb}$. casei during storage in contrast with control. Nevertheless, it was observed significant differences between treatments with 
HTJ through storage period, while there was a slightly significant difference compared to control. Lb. casei counts were growing through 10 days. Then it was shown a little bit decrease at the end of storage in all treatments. These data revealed that various vitamins, essential amino acids, and minerals in the HTJ encourage the growth of probiotics during storage periods. These outcomes are in the same line with El- Sheikha et al., [10], who studied the protein content of Physalis pubescens $L$. fruit, showing $31.8 \%$ of essential amino acids, mainly leucine, lysine, and isoleucine. The juice also contained high amounts of polyunsaturated fatty acids, vitamins A, B, and C, and phytosterols [12, 63].

Moreover, Thuy et al. [64] found that Physalis peruviana contains moderate levels of vitamins ( $\mathrm{C}$ and $\mathrm{A}$ ), antioxidants (polyphenols), minerals (especially high content of phosphorus), and fiber. So, the juice may be considered a good source for probiotic growth. Besides that, several fermented dairy products' quality and shelf life were determined according to the viable count of coliform during storage. Coliforms were not detected in all treatment and control samples during storage, which indicated the good pasteurization and hygienic conditions followed in its production.

Table 5. Viable counts of $L b$. casei of Stirred Probiotic Yogurt (SPY) during storage( $\left.\log _{10} \mathrm{CFU} / \mathrm{ml}\right)$.

\begin{tabular}{l|l|c|c|c}
\multirow{2}{*}{ Treatments } & & \multicolumn{3}{|c}{ Storage periods $\mathbf{5}^{\circ} \mathbf{C} / \mathbf{1 5}$ days } \\
\cline { 2 - 5 } & $\mathbf{F r e s h}$ & $\mathbf{5}$ & $\mathbf{1 0}$ & $\mathbf{1 5}$ \\
\hline Control & $8.50^{\mathrm{Cb}}$ & $8.75^{\mathrm{Ae}}$ & $8.60^{\mathrm{Bd}}$ & $8.40^{\mathrm{Cd}}$ \\
\hline $\mathbf{T}_{\mathbf{1}}$ & $8.65^{\mathrm{Da}}$ & $9.00^{\mathrm{Cd}}$ & $9.25^{\mathrm{Ac}}$ & $9.15^{\mathrm{Bc}}$ \\
\hline $\mathbf{T}_{\mathbf{2}}$ & $8.60^{\mathrm{Da}}$ & $9.30^{\mathrm{Cb}}$ & $9.60^{\mathrm{Ab}}$ & $9.50^{\mathrm{Bb}}$ \\
\hline $\mathbf{T}_{\mathbf{3}}$ & $8.55^{\mathrm{Db}}$ & $9.45^{\mathrm{Ca}}$ & $9.70^{\mathrm{Aa}}$ & $9.65^{\mathrm{Ba}}$ \\
\hline $\mathbf{T}_{\mathbf{4}}$ & $8.45^{\mathrm{Cc}}$ & $9.22^{\mathrm{Bc}}$ & $9.35^{\mathrm{Ac}}$ & $9.20^{\mathrm{Bc}}$
\end{tabular}

$\mathrm{T}_{1}, \mathrm{~T}_{2}, \mathrm{~T}_{3}$ and $\mathrm{T}_{4}$ at the ratios which mentioned before. Data expressed as mean of 3 replicates. Means in the same row showing the same capital letters are not significantly different $(\mathrm{p} \leq 0.05)$. Means in the same column showing the same small letters are not significantly different $(\mathrm{p} \leq 0.05)$

3.8. Microorganisms counts ( $\left.\log _{10} \mathrm{CFU} / \mathrm{ml}\right)$ in contaminated husk tomato juice (HTJ) during storage.

The effect of HTJ on pathogenic strains is illustrated in Table 6. It was clear that the counts of pathogenic strains gradually reduced by increasing as time progressed. Also, from this study, it was regarded that $S$. aureus was more significantly $(\mathrm{p}<0.05)$ sensitive to the juice, which decreased from 5.90 to $1.10 \log _{10} \mathrm{CFU} / \mathrm{ml}$ in the viable count followed by A. flavus, which the viable count decreased from 6.00 to $1.80 \log _{10} \mathrm{CFU} / \mathrm{ml}$ at the end of storage. These outcomes were proven that the HTJ had an antioxidant activity that strongly affected the viability of pathogenic and spoilage microorganisms. So, with this evidence, it can be said that Husk Tomato Juice owns antimicrobial properties that keep fermented dairy products safe from food-born pathogen and spoilage during storage as assessed before in Hegazy et al. [ 14 ]. Göztok and Zengin [ 65]elucidated that the fruit extract of $P$. peruviana was prohibited the growing of B. megaterium, P. aeruginosa, E. coli, K. pneumoniae, C. albicans, and C. globrata at different ratios. Also, Shenstone et al. [66] indicated that polyphenol pyrogallol found in different Physalis species have antibacterial properties and effectively used as a pesticide and in pharmaceutical industries.

Table 6. The effect of Husk Tomato Juice (HTJ) on pathogenic strains during storage ( $\left.\log _{10} \mathrm{CFU} / \mathrm{ml}\right)$.

\begin{tabular}{l|l|c|c|c}
\multirow{2}{*}{ Pathogenic strains } & \multicolumn{4}{|c}{ Storage period (days) } \\
\cline { 2 - 5 } & Fresh & $\mathbf{5}$ & $\mathbf{1 0}$ & $\mathbf{1 5}$ \\
\hline Escherichia coli & $6.00^{\mathrm{Aa}}$ & $4.80^{\mathrm{Bb}}$ & $3.18^{\mathrm{Cc}}$ & $2.35^{\mathrm{Da}}$ \\
\hline Staphylococcus aureus & $5.90^{\mathrm{Ab}}$ & $4.20^{\mathrm{Bd}}$ & $3.00^{\mathrm{Cd}}$ & $1.10^{\mathrm{Dd}}$
\end{tabular}




\begin{tabular}{l|c|c|c|c}
\multirow{2}{*}{ Pathogenic strains } & \multicolumn{4}{|c}{ Storage period (days) } \\
\cline { 2 - 5 } & Fresh & $\mathbf{5}$ & $\mathbf{1 0}$ & $\mathbf{1 5}$ \\
\hline Bacillus cereus & $6.15^{\mathrm{Aab}}$ & $5.00^{\mathrm{Ba}}$ & $3.25^{\mathrm{Cb}}$ & $2.00^{\mathrm{Db}}$ \\
\hline Aspergillus flavus & $6.00^{\mathrm{Aa}}$ & $4.55^{\mathrm{Bc}}$ & $3.50^{\mathrm{Ca}}$ & $1.80^{\mathrm{Dc}}$
\end{tabular}

Data expressed as mean of 3 replicates. Means in the same row showing the same capital letters are not significantly different $(\mathrm{p} \leq 0.05)$.

Means in the same column showing the same small letters are not significantly different $(\mathrm{p} \leq 0.05)$.

3.9. Microorganisms count ( $\left.\log _{10} \mathrm{CFU} / \mathrm{ml}\right)$ in contaminated stirred probiotic yogurt (SPY) treatments.

The impact of varied ratios of Husk Tomato Juice (HTJ) in Stirred Probiotic Yogurt (SPY), including contaminated pathogenic strains, as stated in Table 7. The different ratios' counts of different pathogenic strains gradually decreased over time in the treatment samples with HTJ. Contrary to the control samples which the pathogenic counts remained stable during storage. Also, the $\mathrm{T}_{3}$ and $\mathrm{T}_{4}$, which contained 40 and $50 \%$ HTJ had a higher effect on pathogenic strains when compared with control. Also, this study found that E. coli and A. flavus were more sensitive to HTJ at different ratios. The viable counts of these strains decreased in $\mathrm{T}_{4}$ from 6.15 and 6.00 to 3.20 and $3.80 \mathrm{Log}_{10} \mathrm{CFU} / \mathrm{ml}$ in finishing of storage, respectively. These results indicated that HTJ had antimicrobial characteristics that can save fermented dairy products from food-borne pathogens and spoilage. Our results are confirmed by Göztok and Zengin [ 65 ].

Table 7. Effect of Husk Tomato Juice (HTJ) in Stirred Probiotic Yogurt (SPY) treatments during storage on the pathogenic strains count ( $\log \mathrm{CFU} / \mathrm{ml})$.

\begin{tabular}{|c|c|c|c|c|c|c|}
\hline \multirow[b]{2}{*}{ Microorganisms } & & \multirow[b]{2}{*}{$\mathbf{T}_{4}$} \\
\hline & Storage period (days) & Control & $\mathbf{T}_{1}$ & $\mathbf{T}_{2}$ & $\mathbf{T}_{3}$ & \\
\hline \multirow{4}{*}{$\begin{array}{l}\text { Escherichia } \\
\text { Coli }\end{array}$} & Fresh & $6.20^{\mathrm{ABa}}$ & $6.25^{\mathrm{Aa}}$ & $6.20^{\mathrm{ABa}}$ & $6.10^{\mathrm{Ba}}$ & $6.15^{\mathrm{Ba}}$ \\
\hline & 5 & $6.00^{\mathrm{Ac}}$ & $6.00^{\mathrm{Ab}}$ & $5.00^{\mathrm{Cb}}$ & $5.30^{\mathrm{Bb}}$ & $5.00^{\mathrm{Cb}}$ \\
\hline & 10 & $6.10^{\mathrm{Aab}}$ & $5.30^{\mathrm{Bc}}$ & $4.50^{\mathrm{Cc}}$ & $4.40^{\mathrm{Cc}}$ & $4.20^{\mathrm{Dc}}$ \\
\hline & 15 & $5.95^{\mathrm{Ac}}$ & $5.00^{\mathrm{Bd}}$ & $4.10^{\mathrm{Cd}}$ & $3.35^{\mathrm{Dd}}$ & $3.20^{\mathrm{Ed}}$ \\
\hline \multirow{4}{*}{$\begin{array}{l}\text { Staphylococcus } \\
\text { aureus }\end{array}$} & Fresh & $6.10 \mathrm{~A}^{\mathrm{Ba}}$ & $6.20^{\mathrm{Aa}}$ & $6.10^{\mathrm{ABa}}$ & $6.00^{\mathrm{Ca}}$ & $6.20^{\mathrm{Aa}}$ \\
\hline & 5 & $6.00^{\mathrm{Ab}}$ & $6.00^{\mathrm{Ab}}$ & $5.60^{\mathrm{Bb}}$ & $5.20^{\mathrm{Cb}}$ & $5.20^{\mathrm{Cb}}$ \\
\hline & 10 & $6.20^{\mathrm{Aa}}$ & $5.45^{\mathrm{Bd}}$ & $5.00^{\mathrm{Cc}}$ & $4.80^{\mathrm{Dc}}$ & $4.20^{\mathrm{Ec}}$ \\
\hline & 15 & $6.00^{\mathrm{Ab}}$ & $5.80^{\mathrm{Bc}}$ & $4.30^{\mathrm{CDd}}$ & $4.45^{\mathrm{Cd}}$ & $4.00^{\mathrm{Dd}}$ \\
\hline \multirow{4}{*}{ Bacillus cereus } & Fresh & $6.30^{\mathrm{Aa}}$ & $6.25^{\mathrm{Ba}}$ & $6.25^{\mathrm{Ba}}$ & $6.20^{\mathrm{Ca}}$ & $6.20^{\mathrm{Ca}}$ \\
\hline & 5 & $6.00^{\mathrm{Ab}}$ & $6.00^{\mathrm{Ab}}$ & $5.65^{\mathrm{Bb}}$ & $5.45^{\mathrm{Cb}}$ & $5.25^{\mathrm{Db}}$ \\
\hline & 10 & $6.10^{\mathrm{Ab}}$ & $5.60^{\mathrm{Bc}}$ & $5.20^{\mathrm{Cc}}$ & $5.00^{\mathrm{Dc}}$ & $4.75^{\mathrm{Ec}}$ \\
\hline & 15 & $5.90^{\mathrm{Ac}}$ & $5.20^{\mathrm{Bd}}$ & $4.85^{\mathrm{Cd}}$ & $4.50^{\mathrm{Dd}}$ & $4.10^{\mathrm{Ed}}$ \\
\hline \multirow{4}{*}{$\begin{array}{l}\text { Aspergillus } \\
\text { Flavus }\end{array}$} & Fresh & $6.10^{\mathrm{Ba}}$ & $6.20^{\mathrm{Aa}}$ & $6.00^{\mathrm{Ca}}$ & $6.15^{\mathrm{ABa}}$ & $6.00^{\mathrm{Ca}}$ \\
\hline & 5 & $6.00^{\mathrm{Ab}}$ & $5.80^{\mathrm{Bb}}$ & $5.35^{\mathrm{Cb}}$ & $5.25^{\mathrm{CDb}}$ & $5.20^{\mathrm{Db}}$ \\
\hline & 10 & $6.15^{\mathrm{Aa}}$ & $5.50^{\mathrm{Bc}}$ & $5.00^{\mathrm{Cc}}$ & $4.95^{\mathrm{Dc}}$ & $4.60^{\mathrm{Ec}}$ \\
\hline & 15 & $5.90^{\mathrm{Ac}}$ & $4.85^{\mathrm{Bd}}$ & $4.70^{\mathrm{Cd}}$ & $4.55^{\mathrm{Dd}}$ & $3.80^{\mathrm{Ed}}$ \\
\hline
\end{tabular}

$\mathrm{T}_{1}, \mathrm{~T}_{2}, \mathrm{~T}_{3}$ and $\mathrm{T}_{4}$ at the ratios which mentioned before. Data expressed as mean of 3 replicates. Means in the same row showing the same capital letters are not significantly different $(\mathrm{p} \leq 0.05)$. Means in the same column showing the same small letters are not significantly different $(\mathrm{p} \leq 0.05)$.

3.10. Isolation and identification of fungi in fresh husk tomato juice and milk.

Table 8 cleared that some isolated fungi were detected from HTJ and milk used in the manufacturing of SPY. The genus had three identified species, A. niger, A. flavus, and A. versicolor. Also, the identified species were found at a low level. The same Table did not detect mycotoxin produced from these isolates in raw materials before or after the pasteurization process. Moreover, the heat treatment used in pasteurization is sufficient to destroy the detected isolates. The data by Thomma [ 67] and Ostry [68] found that the cold temperature was suitable for the growth of different fungi in food. They observed that about thirty toxins could be produced at low temperatures from some species. , The presence of fungi does not 
mean the production of mycotoxins, which depend on several factors, especially temperature and humidity [69]. The warm temperature at high humidity is the most appropriate condition for mycotoxin production from fungi. Therefore, tropical and subtropical countries such as Colombia, Mexico, and Egypt are susceptible to fungal contamination and mycotoxin production. Also, the storage time \& processing type and their conditions greatly affected contamination with fungi and mycotoxins production [70].

Table 8. Isolated fungi from Husk Tomato Juice (HTJ) and milk before and after pasteurization.

\begin{tabular}{l|c|c|c}
\multirow{2}{*}{ Raw materials } & Fungi detection & before pasteurization & after pasteurization \\
\cline { 2 - 4 } \multirow{2}{*}{ HTJ } & A. versicolor & 2.90 & ND \\
\cline { 2 - 4 } Milk & A. niger & 2.30 & ND \\
\cline { 2 - 4 } & Penicillum sp. & 1.00 & ND \\
\cline { 2 - 4 } & A. niger & ND & ND
\end{tabular}

ND: Not detectable

\subsection{Detection the ability of isolated fungi from SPY to produce mycotoxins.}

From Table 9, it was found that A. niger was detected only in fresh control SPY at the ratio of $2.48 \log \mathrm{cfu} / \mathrm{ml}$, while all treatments hadn't any detected fungi. Also, after 10 days of storage, $\mathrm{T}_{1}$ had got $A$. niger at the ratio $2.60 \mathrm{log} \mathrm{cfu} / \mathrm{ml}$, and $\mathrm{T}_{2}$ had $A$. versicaler at the ratio $2.95 \log \mathrm{cfu} / \mathrm{ml}$. Moreover, the present study used the TLC technique to compare isolated fungi' ability to produce mycotoxins during storage. The investigated mycotoxins included aflatoxin $\mathrm{B}_{1}$ by $A$. flavus and sterigmatocystin by $A$. vesicolor. Our data showed that many isolated species could not be able to produce mycotoxins under-investigated conditions. The main fungal species in the production of mycotoxins are Pencillium and Aspergillus. Their toxins are toxic, mutagenic, and have a significant effect on animal and human health. Approximately three hundred mycotoxins can be produced from the mentioned species. However, only about twenty types are known for their potential effects, reduced animal production, and caused human illness [20]. The obtained results showed that all collected beverage treatments were free from mycotoxins such as aflatoxin and sterigmatocystin. Also, it was demonstrated that the treatments fortified with HTJ were mostly uncontaminated by fungi species; this may be due to the antimicrobial properties of HTJ, as mentioned before by Hegazy et al. [14].

Table 9. Detection of fungi from SPY during storage ( $\mathrm{Log} \mathrm{cfu} / \mathrm{ml})$.

\begin{tabular}{|c|c|c|c|c|c|}
\hline \multirow{2}{*}{ Treatments } & \multirow[t]{2}{*}{ Fungi isolates } & \multirow{2}{*}{ Fresh } & \multicolumn{3}{|c|}{ Storage periods $5^{\circ} \mathrm{C} / 15$ days } \\
\hline & & & 5 & 10 & 15 \\
\hline \multirow{3}{*}{ Control } & A. niger & 2.48 & N.D & N.D & N.D \\
\hline & A. flavus & N.D & N.D & N.D & 2.78 \\
\hline & A. versicaler & N.D & N.D & N.D & N.D \\
\hline \multirow{3}{*}{$\mathbf{T}_{1}$} & A. niger & N.D & N.D & 2.60 & N.D \\
\hline & A. flavus & N.D & N.D & N.D & N.D \\
\hline & A. versicaler & N.D & N.D & N.D & N.D \\
\hline \multirow{3}{*}{$\mathbf{T 2}$} & A. niger & N.D & N.D & N.D & N.D \\
\hline & A. flavus & N.D & N.D & N.D & N.D \\
\hline & A. versicaler & N.D & N.D & 2.95 & N.D \\
\hline \multirow{3}{*}{$\mathbf{T}_{3}$} & A. niger & N.D & N.D & N.D & N.D \\
\hline & A. flavus & N.D & N.D & N.D & N.D \\
\hline & A. versicaler & N.D & N.D & N.D & N.D \\
\hline \multirow{3}{*}{$\mathbf{T 4}$} & A. niger & N.D & N.D & N.D & N.D \\
\hline & A. flavus & N.D & N.D & N.D & N.D \\
\hline & A. versicaler & N.D & N.D & N.D & N.D \\
\hline
\end{tabular}

ND: Not detectable. $T_{1}, T_{2}, T_{3}$ and $T_{4}$ at the ratios mentioned before. 


\section{Conclusions}

A novel fermented beverage was successfully produced fortified with probiotics and Husk Tomato Juice. Adding HTJ positively affected the beverage contents of vitamins, amino acids, and vitamin C. Also, this juice has a strong antimicrobial activity. The final product was free from any pathogenic bacteria, fungi, and mycotoxins. So, it was recommended that the addition of HTJ increased the product's shelf life and enhanced probiotic bacteria.

\section{Funding}

This research received no external funding.

\section{Acknowledgments}

This research has no acknowledgment.

\section{Conflicts of Interest}

The authors declare no conflict of interest.

\section{References}

1. Marsh, A.J.; Hill, C.; Ross, R.P.; Cotter, P.D. Fermented beverages with health-promoting potential: Past and future perspectives. Trends in Food Science \& Technology 2014, 38, 113-124, https://doi.org/10.1016/j.tifs.2014.05.002.

2. Blassy, k.; Osman, M.; Gouda, A. and Hamed,M. Functional Properties of Yoghurt Fortified with Fruits Pulp. Ismailia Journal of Dairy Science \& Technology; Suez Canal University 2020, 7, 1-9.

3. Jovanovi'c, M.; Petrovi'c, M.; Mio cinovi'c, J.;Zlatanovi'c, S.; Petronijevi'c, J. L.; Miti'c-Culafi'c ', D. and Gorjanovi'c , S. Bioactivity and Sensory Properties of Probiotic Yogurt Fortified with Apple Pomace Flour. Foods 2020, 9, 763, https:/doi.org/10.3390/foods9060763.

4. Parvez, S.; Malik, K.A.; Ah Kang, S.; Kim, H.Y. Probiotics and their fermented food products are beneficial for health. Journal of Applied Microbiology 2006, 100, 1171-1185, https://doi.org/10.1111/j.13652672.2006.02963.x.

5. Panesar, P. Fermented Dairy Products: Starter Cultures and Potential Nutritional Benefits. Food and Nutrition Sciences 2011, 2, 47-51, https://doi.org/10.4236/fns.2011.21006.

6. Hasneen, D. F.; Zaki, N. L.; Abbas, M. S.; Soliman, A. S.; Ashoush, I. S. and Fayed, A. E. Comparative evaluation of some herbs and their suitability for skimmedmilk yoghurt and cast Kariesh cheese fortification as functional foods. Annals of Agricultural Sciences 2020, 65, 6-12, https://doi.org/10.1016/j.aoas.2020.05.001.

7. Jalal, H.; Para, P.; Ganguly, S.; Devi; Bhat; Bukhari; Qadri. Fortification of Dairy Products: A Review. World Journal of Biology and Medical Sciences 2016, 3, 23-35.

8. Ismail, S. A.; El-Sayed, H. S.; Fayed, B. Production of prebiotic chitooligosaccharide and its nano/microencapsulation for the production of functional yoghurt. Carbohydrate polymers $\mathbf{2 0 2 0}$, 234, 115941, https://doi.org/10.1016/j.carbpol.2020.115941

9. Gupta, M.; Sharma, S. Probiotics in limelight. Journal of Innovative Biology 2016, 3, 276-280.

10. Preedy, V.R.; Srirajaskanthan, R.; Patel, V.B. Handbook of Food Fortification and Health. Humana Press, New York. 2013.

11. Miller, G.D.; Jarvis, J.K.; McLean, L.D. Handbook of Dairy Foods and Nutrition. CRC Press. 2006.

12. El Sheikha, A.; Zaki, M.S.; Bakr, A.A.; Habashy, M.M.; Montet, D. Physico-chemical properties and biochemical composition of Physalis (Physalis pubescens L.) fruits. Food 2008, 2, 124-130.

13. El Sheikha, A.; Piombo, G.; Goli, T.; Montet, D. Main composition of Physalis (Physalis pubescens L.) fruit juice from Egypt. Fruits 2010, 65, 255-265, https://doi.org/10.1051/fruits/2010021.

14. Hegazy, E.; Ali, A.; S. El-Sayed, H.; Kassem, J. Quality Properties of Husk Tomato Juice and Its Impact in Stirred Probiotic Yogurt. Asian Food Science Journal 2019, 7, 1-10, https://doi.org/10.9734/afsj/2019/v7i229962.

15. Franco, L.A.; Matiz, G.E.; Calle, J.; Pinzón, R.; Ospina, L.F. [Antiinflammatory activity of extracts and fractions obtained from Physalis peruviana L. calyces]. Biomedica : revista del Instituto Nacional de Salud 2007, 27, 110-115. 
16. Wu, S.J.; Tsai, J.Y.; Chang, S.P.; Lin, D.L.; Wang, S.S.; Huang, S.N.; Ng, L.T. Supercritical carbon dioxide extract exhibits enhanced antioxidant and antiinflammatory activities of Physalis peruviana. Journal of Ethnopharmacology 2006, 108, 407-413, https://doi.org/10.1016/j.jep.2006.05.027.

17. Wagacha, J.M.; Muthomi, J.W. Mycotoxin problem in Africa: Current status, implications to food safety and health and possible management strategies. International Journal of Food Microbiology 2008, 124, 1-12, https://doi.org/10.1016/j.ijfoodmicro.2008.01.008.

18. Vargas-Ponce, O.; Pérez-Álvarez, L.F.; Zamora-Tavares, P.; Rodríguez, A. Assessing Genetic Diversity in Mexican Husk Tomato Species. Plant Molecular Biology Reporter 2011, 29, 733-738, https://doi.org/10.1007/s11105-010-0258-1.

19. Turner, N.W.; Subrahmanyam, S.; Piletsky, S.A. Analytical methods for determination of mycotoxins: A review. Analytica Chimica Acta 2009, 632, 168-180, https://doi.org/10.1016/j.aca.2008.11.010.

20. Bhat, R.; Rai, R.V.; Karim, A.A. Mycotoxins in Food and Feed: Present Status and Future Concerns. Comprehensive Reviews in Food Science and Food Safety 2010, 9, 57-81, https://doi.org/10.1111/j.15414337.2009.00094.x.

21. Goncalves, L.; Dalla Rosa, A.; Gonzales, S.L.; Feltes, M.M.C.; Badiale-Furlong, E.; Dors, G.C. Incidence of aflatoxin M1 in fresh milk from small farms. Food Science and Technology, Campinas 2017, 37, 11-15, https://doi.org/10.1590/1678-457X.06317.

22. Marshall, V.M.; Rawson, H.L. Effects of exopolysaccharide-producing strains of thermophilic lactic acid bacteria on the texture of stirred yoghurt. International Journal of Food Science \& Technology 1999, 34, 137143, https://doi.org/10.1046/j.1365-2621.1999.00245.x.

23. Danish Official. HPLC method No.AF 255.1. $3^{\text {th }}$ ed. National Food Agency of Denmark. 1996.

24. Danish Official. HPLC method No. AB 198.2. National Food Agency of Denmark. 1996.

25. Indian Standard Methods For Estimation Of Vitamin C in Foodstuffs. 1970.

26. AOAC. Association of Official Analytical Chemists. Official Methods of Analysis. $19^{\text {th }}$ Ed., Gaithersburg, M D, USA. 2012.

27. Hunter, R.S. Scales for Measurements of Color Difference. In: The Measurement of Appearance. Hunter, R.; Harold, R.W. (Eds.). Wiley-Inter science, New York, 1975; pp: 162-192.

28. De Man, J.C.; Rogosa, M.; Sharpe, M.E. A Medium For The Cultivation Of Lactobacilli. Journal of Applied Bacteriology 1960, 23, 130-135, https://doi.org/10.1111/j.1365-2672.1960.tb00188.x.

29. Terzaghi, B.E.; Sandine, W.E. Improved medium for lactic streptococci and their bacteriophages. Applied microbiology 1975, 29, 807-813.

30. El-Shafei, K.; Elshaghabee, F.M.F.; El-Sayed, H.S; Kassem, J.M. Assessment the Viability Properties of Lactobacillus casei Strain Using Labneh as a Carrier. Acta Scientiarum Polonorum Technologia Alimentaria 2018, 17(3), 267-276, https://doi.org/10.17306/J.AFS.2018.0583.

31. Mossel, D.A.A. Media for Enterobacteriaceae. International Journal of Food Microbiology 1985, 2, 27-32, https://doi.org/10.1016/0168-1605(85)90053-4.

32. FDA, Food and Drug Administration. Bacteriological Analytical Manual. $9^{\text {th }}$ Ed., AOAC Int., Arlington, VA, USA. 2002.

33. March, S.B.; Ratnam, S. Sorbitol-MacConkey medium for detection of Escherichia coli O157:H7 associated with hemorrhagic colitis. J Clin Microbiol 1986, 23, 869-872, https://doi.org/10.1128/jcm.23.5.869-872.1986.

34. Baird-Parker, A.C. An Improved Diagnostic And Selective Medium For Isolating Coagulase Positive Staphylococci. Journal of Applied Bacteriology 1962, 25, 12-19, https://doi.org/10.1111/j.13652672.1962.tb01113.x.

35. APHA. Standard Methods for Examination of Dairy Products. $16^{\text {th }}$ Ed., American Public Health Association Washington, DC., USA. 1994.

36. Nure, M.; Abubakar, A.; Auyo, M.I.; Sunday, E.; Kutama, A.S. Isolation and Identification of fungi associated with Tigernut milk drink (KununAya) in Dutse, Jigawa state. Global Advanced Research Journal of Agricultural Science 2016, 5, 302-308.

37. APHA. American Public Health Association. Methods for the Microbiological Examination of food. $3^{\text {rd }}$ ed Washington D.C. Volume 71, 1992; pp. 1406-1411.

38. Barnett, H.L.; Hunter, B.B. Illustrated of imperfect fungi. 4th ed, APS Press, st. PaulMinnesota, USA, 1998; pp: 218.

39. Muiz Al-Hussaini, I.; Kadhim, K.H. Molecular diagnosis of patulin toxic produced from Penicillium expansum in apples fruits. Mesopotemia Environmental Journal 2017, A, 111-120.

40. AOAC. Association of official analytical chalet. Natural toxins official methods of AOAC International. V2, Chapter 49, 17 , Edited by Horwitz, W. 2002; pp. 1-64.

41. Giovati, L.; Magliani, W.; Ciociola, T.; Santinoli, C.; Conti, S.; Polonelli, L. AFM1 in Milk: Physical, Biological, and Prophylactic Methods to Mitigate Contamination. Toxins 2015, 7, 4330-4349., https://doi.org/10.3390/toxins7104330.

42. SAS. SAS User's Guide: Statistics, Version 6.04. $4^{\text {th }}$ Ed., SAS Inst. Inc., Cary, NC., USA. 2004.

43. Hassanien, M.; Mörsel, J.T. Goldenberry, a novel fruit, source of fat-soluble bioactives. INFORM International News on Fats, Oils and Related Materials 2004, 15, 130-131. 
44. Labarca, V.B.; Vicuna, C.G.; Alvarez, P.F.; Fuentes, I.Q.; Won, M.P. Extraction of $\beta$-carotene, vitamin C and antioxidant compounds from Physalisperuviana(Cape gooseberry) assisted by high hydrostatic pressure. Food and Nutrition Sciences 2013, 4, 109-118, https://doi.org/10.4236/fns.2013.48A014.

45. Skrovankova, S.; Sumczynski, D.; Mlcek, J.; Jurikova, T.; Sochor, J. Bioactive Compounds and Antioxidant Activity in Different Types of Berries. International Journal of Molecular Sciences 2015, 16, 24673-24706. https://doi.org/10.3390/ijms161024673.

46. World Health Organization (WHO). WHO Guideline. Vitamin A supplementation in infants and children 659 months of age. 2011.

47. Khedkar, C.D.; Kalyankar, S.D.; Deosarkar, S.S. Buffalo Milk. In: Encyclopedia of Food and Health. Caballero, B.; Finglas, P.; Toldrá, F. (eds.), Oxford: Academic Press. Volume 1, 2016, pp. 522-528.

48. Pritwani, R.; Mathur, P. $\beta$-carotene Content of Some Commonly Consumed Vegetables and Fruits Available in Delhi, India. Journal of nutrition and food sciences 2016, 7, 1-7, https://doi.org/10.4172/21559600.1000625.

49. Anon. Energy and protein requirement. Rep. Joint FAO / WHO / UNU (Food Agric. Organ. /World Health Organ. / U. N. Union) Meet. Ser. No. 724, WHO, Geneva, Switz., 1985.

50. Colovic, M.B.; Vasic, V.M.; Djuric, D.M.; Krstic, D.Z. Sulphur-containing Amino Acids: Protective Role Against Free Radicals and Heavy Metals. Curr Med Chem 2018, 25, 324-335, https://doi.org/10.2174/0929867324666170609075434.

51. Rozada-Sánchez, R.; Sattur, A.P.; Thomas, K.; Pandiella, S.S. Evaluation of Bifidobacterium spp. for the production of a potentially probiotic malt-based beverage. Process Biochemistry 2008, 43, 848-854, https://doi.org/10.1016/j.procbio.2008.04.002.

52. Gustaw, W.; Kordowska-Wiater, M.; Kozioł, J. The influence of selected prebiotics on the growth of lactic acid bacteria for bio-yoghurt production. Acta scientiarum polonorum. Technologia alimentaria 2011, 10, 455-466.

53. El-Sayed, H.; Ramadan, M. Production Of Probiotic-Fermented Rice Milk Beverage Fortified With Cactus Pear And Physalis Pulp. Zagazig Journal of Agricultural Research 2020, 47, 165-177, https://doi.org/10.21608/zjar.2020.70239.

54. Rawson, H.L.; Marshall, V.M. Effect of 'ropy' strains of Lactobacillus delbrueckii ssp. bulgaricus and Streptococcus thermophilus on rheology of stirred yogurt. International Journal of Food Science \& Technology 1997, 32, 213-220, https://doi.org/10.1046/j.1365-2621.1997.00395.x.

55. Béal, C.; Helinck, S. Yogurt and other fermented milks. In: Microorganisms and fermentation of traditional foods. 1st ed. Ray, R.; Didier, M. ed., Boca Raton: CRC Press 2015; pp. 141-181.

56. Han, X.; Yang, Z.; Jing, X.; Yu, P.; Zhang, Y.; Yi, H.; Zhang, L. Improvement of the Texture of Yogurt by Use of Exopolysaccharide Producing Lactic Acid Bacteria. BioMed Research International 2016, 2016, https://doi.org/10.1155/2016/7945675.

57. Mekhici, B.K.; Meddah, T.T.A.; Boumédiene, M. Optimization of production of Microbial Exopolysaccharides (EPS) with essential oils from two medicinal plants. Journal of Applied Biosciences 2017, 111, 10925-10933.

58. Sahan, N.; Yasar, K.; Hayaloglu, A.A. Physical, chemical and flavour quality of non-fat yogurt as affected by a $\beta$-glucan hydrocolloidal composite during storage. Food Hydrocolloids 2008, 22, 1291-1297, https://doi.org/10.1016/j.foodhyd.2007.06.010.

59. Gilbert, A.; Rioux, L. E.; St-Gelais, D. and Turgeon, S. L. Studying stirred yogurt microstructure using optical microscopy: How smoothing temperature and storage time affect microgel size related to syneresis. J. Dairy Sci. 2020, 103, 2139-2152, https://doi.org/10.3168/jds.2019-16787.

60. Yu, M.-S.; Kim, J.-M.; Lee, C.-H.; Son, Y.-J.; Kim, S.-K. Quality Characteristics of Stirred Yoghurt Added with Fermented Red Pepper. Korean J Food Sci Anim Resour 2014, 34, 408-414.

61. Nguyen, L.; Hwang, E.S. Quality Characteristics and Antioxidant Activity of Yogurt Supplemented with Aronia (Aronia melanocarpa) Juice. Preventive nutrition and food science 2016, 21, 330-337,

62. Mayorga, H.; Knapp, H.; Winterhalter, P.; Duque, C. Glycosidically Bound Flavor Compounds of Cape Gooseberry (Physalis peruviana L.). J Agric Food Chem 2001, 49, 1904-1908, https://doi.org/10.1021/jf0011743.

63. Ramadan, M.F.; Mörsel, J.-T. Oil Goldenberry (Physalis peruviana L.). J Agric Food Chem 2003, 51, 969974, https://doi.org/10.1021/jf020778z.

64. Thuy, N. M.; Phuong, N. P.; C. Suong T. D. and Tai. N. V. Physical and chemical characteristics of goldenberry (Physalis peruviana) grown in Lam Dong province, Vietnam. Food Research 2020, 4 (4) 12171225, https://doi.org/10.26656/fr.2017.4(4).085

65. Göztok, F.; Zengin, F. The antimicrobial activity of Physalis peruviana L. Bitlis Eren University Journal of Science and Technology 2015, 3, 15-17, https://doi.org/10.17678/beuscitech.47134.

66. Shenstone, E.; Lippman, Z.; Van Eck, J. A review of nutritional properties and health benefits of Physalis species. Plant foods for human nutrition (Dordrecht, Netherlands) 2020, 75, 316-325, https://doi.org/10.1007/s11130-020-00821-3.

67. Thomma, B.P.H.J. Alternaria spp.: from general saprophyte to specific parasite. Molecular Plant Pathology 2003, 4, 225-236, https://doi.org/10.1046/j.1364-3703.2003.00173.x. 
68. Ostry, V. Alternaria mycotoxins: An overview of chemical characterization, producers, toxicity, analysis and occurrence in foodstuffs. World Mycotoxin Journal 2008, 1, 175-188, https://doi.org/10.3920/WMJ2008.x013.

69. Binder, E.M.; Tan, L.M.; Chin, L.J.; Handl, J.; Richard, J. Worldwide occurrence of mycotoxins in commodities, feeds and feed ingredients. Animal Feed Science and Technology 2007, 137, 265-282, https://doi.org/10.1016/j.anifeedsci.2007.06.005.

70. Miller, G.D.; Jarvis, J.K.; McLean, L.D. Handbook of Dairy Foods and Nutrition. CRC Press. 2006. 